\title{
A Sustainable Impact Assessment Approach to Integrated Watershed Development Programme in Nagaland, India
}

\author{
S. Kanitoli Chishi and Amod Sharma* \\ Department of Agricultural Economics, Nagaland University SASRD, Medziphema Campus, \\ District: Dimapur - 797 106, Nagaland, India \\ *Corresponding author
}

\begin{tabular}{|l|}
\hline K e y w o r d s \\
IWDP, Impact, \\
$\begin{array}{l}\text { Assessment, Economics, } \\
\text { Beneficiaries, Non- } \\
\text { beneficiaries }\end{array}$ \\
\hline Article Info \\
\hline $\begin{array}{l}\text { Accepted: } \\
12 \text { October } 2018 \\
\text { Available Online: } \\
10 \text { November } 2018\end{array}$ \\
\hline
\end{tabular}

\section{Introduction}

It has been essential in a country like India where majority of the population depends on agriculture and about 60.00 percent of total arable land (142 million ha) in the country is rainfed (Raju et al., 2012). A large portion of the rainfed areas $(65.00$ per cent of arable land) in India is characterised by low productivity, high risk and uncertainty, low level of technological change and
The present study to access the sustainable impact of watershed on the level of economics with especial reference to the beneficiaries and non-beneficiaries for the purpose two districts viz., Dimapur and Zunheboto were selected purposely, while two blocks from each district were randomly selected, out of that 8 numbers of watersheds areas were selected. In the second stage of sampling a multi-stage random sampling was used for the selection of beneficiary and non-beneficiary viz., 160 respondents ( 80 beneficiaries and 80 non-beneficiaries) by random method from the identified watershed areas. Further, study reveals that the net returns of overall net returns on the beneficiaries was Rs 18,31,370.00/as compared to Rs $11,56,914.00 /-$ the non-beneficiaries. While on the large farms was found to highest percent increase in net return over small, semi-medium and medium farmers, respectively. Also, it is found that the marginal propensity to consume (MPC) was highest for semi-medium farmers (0.91), as compared to medium (0.46), small farmers $(0.44)$ and (0.05) large farmers, respectively. The overall average size of land holding of beneficiary is 21.75 ha as compared to non-beneficiary (21.16 ha). The main constraints faced by the farmers in the implementation of IWMP is the infra-structural problem of lack of machines, equipment, lack of awareness about finance facilities, lack of transportation facilities, lack of information system, lack of knowledge about bunds and also unavailability of marketing facilities etc. 
(CGIAR) and its allied agencies amongst others have emphasized sustainable use of water and other natural resources (Sharma, 2002; Sharma, 2014).

Watershed Development Programmes (WDPs) have been accorded high priority in India's development plan. These programmes have been initiated in India to improve and sustain productivity and the production potential of the dry and semi-arid regions of the country through the adoption of appropriate production and conservation techniques (Prato and Kajkowiz, 1999). The WDP approach seeks to improve and develop all types of land viz., government forest, community land and private land; that fall within a particular watershed. It is a holistic approach to improve and develop the economic and natural resource base of dry and semi-arid regions (Raju et al., 2015).

The IWMP programme have stressed upon improvement of wasteland, runoff reduction, water conservation and protective irrigation mechanism in all areas including desert prone areas and drought prone areas. Development programs, envisaged under its purview include almost every activity which concerns land, water and bio-mass production (Prato, 1999). Experiences have shown that watershed as a base is very effective in use and management of land and water resources (Ninan and Lakhikanthanan, 2001). With increasing awareness about the problems related to environment, use of watershed terminology is becoming popular and moreover in view of their potential for growth, improvement in income levels and augmenting the natural resource base of the disadvantaged regions of the country (Panna et al., 2017).

\section{Objectives}

The present research study is having two specific objectives:
To study the different activities implemented in the Integrated Watershed Management Programme, and

To study the economic status of different activities of Integrated Watershed Management Programme.

\section{Materials and Methods}

The present study is related to IWMP scheme, which is working as per the guideline of Central government with the help of Ministry of Agriculture, Government of India (Chandel, 1984). Development projects require long period of time to reap benefits. Therefore for economic appraisal of development projects, it is essential that the project has been in operation for quite some time. Since the intensive IWMP started in 2008-09 (Anon., 2012), so it is worth, while to study its impact. Since the data of the initial period cannot be compared with the data of recent years. It is more scientific and practical to compare the economy of the beneficiaries and nonbeneficiaries covered in the area of IWMP schemes (Anon., 2017).

The IWMP was launched in 2008-09 in all 11 district viz., Dimapur, Kohima, Kiphire, Longleng, Mokokchung, Mon, Phek, Peren, Tuensang, Wokha and Zunheboto of Nagaland, out of these districts two districts namely, Zunheboto and Dimapur districts of Nagaland selected because of the fact that it is expected to provide all the relevant information and hence can conveniently be obtained for conducting this study. The project area also has a good network of infrastructure and allied activities related to the scheme such as development agencies, nationalized banks, well-established marketing and communication facilities etc. Keeping all the above facts, both districts of Nagaland are therefore purposively selected to conduct this study. Two blocks from each district will be 
selected randomly for the present study as those are well covered by IWMP programme. Altogether eight villages were selected randomly from each district, while four villages from each block will be selected, after selection of the villages, list of beneficiaries and non-beneficiaries of IWMP will be prepared from each of the selected village. In order to have representative sample from each village a sample of 20 numbers of cases of IWMP, out of that 10 from beneficiaries and 10 from non-beneficiaries will be drawn following the purposively random sampling method. This will result in selection of 160 respondents from 8 villages, out of which 80 will be beneficiaries of IWMP scheme and 80 will be non-beneficiaries of IWMP scheme. The study will be based on primary and secondary data, Secondary data will be collected from secondary sources viz, office of the Project Director, IWMP Zunheboto and Dimapur various published materials from the Directorate of Agriculture, Government of Nagaland, etc. In order to identify the constraints in implementing the IWMP programme discussion with IWMP functionaries at district level / block level etc. will be conducted. Besides, data on demographic features, land use pattern, livestock population, climate, rainfall, area under irrigation; institutional infrastructure etc. will also be collected from various statistical abstracts of the districts and state which will enlighten the socio-economic and infrastructural scenario of the area under study. The primary data will be collected through pre-tested and pre-structured schedules and questionnaires' especially designed for this study.

\section{Analytical techniques and tools}

The changes in the consumption by the beneficiaries were assessed by calculating marginal propensity to consume (MPC) (McDonald and John, 1999).
$\mathrm{MPC}=\Delta \mathrm{C} / \Delta \mathrm{Y}$

$=$ Changes in consumption / Changes in income

Whereas:

MPC $=$ Marginal propensity to consume, $\mathrm{C}=$ Expenditure on consumption items, $\mathrm{Y}=$ Income of the family.

\section{Results and Discussion}

Table 1 reveals that the different Entry point activity carried out under IWMP in Nagaland, we can see that constructions of water tank / pond / reservoir has been carried in most of the village with a total of 393 villages, followed by construction of marketing shed in 115 villages, construction of toilet in 75 villages, construction of footstep and waiting shed in 66 villages, construction community hall / repair or renovation of community hall carried out in 56 villages, construction of community kitchen / guest house/building/post-harvest storage unit carried out in 32 villages, distribution of plastic chairs in 27 villages, construction of ring well carried out in 19 villages, construction of rostrum and approach road / repairing of road are carried out in 18 villages, fencing of project site has been carried out in 16 villages, construction of retaining wall carried out in 11 villages, pipeline for water reservoir is carried out in 10 villages, construction of culvert in 8 villages, sugarcane crushing machine set up in 7 villages, drainage and renovation of school has been carried in 6 villages, generator and rice mill has been set up in 4 villages, construction of community fishery pond, connection of street light / solar light, purchasing of syntex tank / water barrels, furniture / utensils has been carried out 3 villages, setting up of Bamboo charcoal making hearth, check dam, hand pump, agar distillation unit has been carried out in only 1 village each. 
Table.1 Different Entry point activity carried out under IWMP in Nagaland

\begin{tabular}{|c|c|c|c|}
\hline S. N. & Name of the works & Village & Area (ha) / No's \\
\hline 1. & Marketing Shed & 115 & 125 Nos. \\
\hline 2. & Ring-well & 19 & 25 Nos. \\
\hline 3. & Water tank / pond / reservoir & 393 & 488 Nos. \\
\hline 4. & Community hall / renovation of community hall & 56 & 61 Nos. \\
\hline 5. & Toilets & 75 & 946 Nos. \\
\hline 6. & Footstep & 66 & 6,121 feet \\
\hline 7. & Fencing of project site & 16 & 206 rolls \\
\hline 8. & Generator & 4 & 4 Nos. \\
\hline 9. & Community kitchen / guest house / PH storage building unit & 32 & 36 Nos. \\
\hline 10. & Renovation of school building & 6 & 6 Nos. \\
\hline 11. & Rostrum & 18 & 18 Nos. \\
\hline 12. & Approach road / repairing of road & 18 & $25.78 \mathrm{Km}$ \\
\hline 13. & Community fishery pond & 3 & 3 Nos. \\
\hline 14. & Bamboo charcoal making hearth & 1 & 1 Nos. \\
\hline 15. & Waiting shed & 66 & 67 Nos. \\
\hline 16. & Culvert & 8 & 8 Nos. \\
\hline 17. & Street light / Solar light & 3 & 3 Nos. \\
\hline 18. & Plastic chair & 27 & 2,597 Nos. \\
\hline 19. & Check dam & 1 & 1 \\
\hline 20. & Syntex / water barrels & 3 & 116 Nos. \\
\hline 21. & Retaining wall & 11 & 4,039 feet \\
\hline 22. & Hand pump & 1 & 150 feet \\
\hline 23. & Purchase of furniture / utensils & 3 & - \\
\hline 24. & Drainage & 6 & 6 Nos. \\
\hline 25. & Sugarcane crushing machine & 7 & 7 Nos. \\
\hline 26. & Pipeline for water reservoir & 10 & 5,160 metres \\
\hline 27. & Rice-mill & 4 & 4 Nos. \\
\hline 28. & Agar distillation unit & 1 & 1 Nos. \\
\hline 29. & Others (Granary, Gate, Basketball court, soil metailing etc;) & 17 & 17 Nos. \\
\hline & Overall & 990 & - \\
\hline
\end{tabular}

(Source: Department of Land resource, Nagaland, 2017) 
Table.2 Different activities implemented under IWMP for the beneficiary

\begin{tabular}{|c|l|c|c|}
\hline S. N. & \multicolumn{1}{|c|}{ Activity Implemented } & Numbers & Per cent \\
\hline 1. & Trainings & 56 & 16.62 \\
\hline 2. & Exposure trips & 25 & 7.42 \\
\hline 3. & Demonstration and Exhibition & 38 & 11.28 \\
\hline 4. & Distribution of saplings & 78 & 23.15 \\
\hline 5. & Agri-based activity & 26 & 7.72 \\
\hline 6. & Animal husbandry & 40 & 11.86 \\
\hline 7. & Funding of SHG & 62 & 18.39 \\
\hline 8. & Others Overall & 12 & 3.56 \\
\hline
\end{tabular}

Table.3 Marginal propensity to consume (in Rs)

\begin{tabular}{|c|l|r|r|r|} 
S. N. & \multicolumn{1}{|c|}{ Category } & $\begin{array}{l}\text { Total } \\
\text { consumption } \mathbf{e x p}(\Delta \mathbf{C})\end{array}$ & $\begin{array}{l}\text { Total } \\
\text { income }(\Delta \mathbf{Y})\end{array}$ & $\begin{array}{l}\text { incremental } \\
\text { MPC }=\end{array}$ \\
\hline 1. & Small farmers & $28,800.00$ & $66,000.00$ & 0.44 \\
\hline 2. & Semi-medium & $3,57,460.00$ & $3,92,800.00$ & 0.91 \\
\hline 3. & Medium farmers & $4,22,010.00$ & $9,28,140.00$ & 0.46 \\
\hline 4. & Large farmers & $5,39,100.00$ & $11,544,094.00$ & 0.05 \\
\hline & Overall & $13,47,370.00$ & $12,931,034.00$ & 0.10 \\
\hline
\end{tabular}

Table.4 Additional employment generated by the crop activities (mandays/year/family)

\begin{tabular}{|c|l|c|c|c|c|}
\hline S. N. & \multicolumn{1}{|c|}{ Category } & $\begin{array}{c}\text { Beneficiary } \\
\text { farms }\end{array}$ & $\begin{array}{c}\text { Non-beneficiary } \\
\text { farms }\end{array}$ & $\begin{array}{c}\text { Absolute } \\
\text { change }\end{array}$ & $\begin{array}{c}\text { Per cent } \\
\text { change }\end{array}$ \\
\hline 1. & Small & 44.10 & 38.20 & 5.90 & 31.05 \\
\hline 2. & Semi-medium & 65.40 & 60.00 & 5.40 & 28.42 \\
\hline 3. & Medium & 78.00 & 73.00 & 5.00 & 26.32 \\
\hline 4. & Large & 82.00 & 79.30 & 2.70 & 14.21 \\
\hline & Overall & 269.50 & 250.50 & 19.00 & 100.00 \\
\hline
\end{tabular}

Miscellaneous work like construction of granary, village gate, basketball court, soil metalling etc; has been carried out in 17 villages.

Table 2 reveals that the fore most common activity implemented under the Integrated Watershed Management Programme (IWMP) scheme was the distribution of saplings (23.15 per cent), followed by funding of Self Help Group's (SHG's) (18.39 per cent), the third was trainings with 16.62 per cent, while animal husbandry ranked fourth with 11.86 per cent, the demonstration and exhibition was of fifth rank with 11.28 per cent, sixth rank was of agri-based activity with 7.72 per cent and the last place was of exposure trips with 7.42 per cent, respectively.

Table 3 reveals that the marginal propensity to consume of the respondent among the different group of land holders, so to work out 
the present purpose over the changes in the consumption based on the income of the family / households items by the beneficiaries were assessed by calculating marginal propensity to consume. Based on the formula, it is found that the marginal propensity to consumption / consume items was highest for semi-medium farmers it was 0.91 as compared to medium with 0.46 , on small farmers it was 0.44 , while it was found to be 0.05 on large farmers, while on the overall farmers the MPC was found to 0.10 , respectively. Similar studies were also carried out by Oral et al., (1998); Barden and Vanierland (1999); Dui (1999); Mehnet and Sermin (2011); Mishra et al., (2014); Walling et al., (2017), Paney and Sharma (2018).

Table 4 reveals that per family additional employment generated through the crop enterprise / activities on beneficiary was 269.50 mandays as compare to nonbeneficiary farmers was of 250.50 mandays, even the percentage change was clearly indicated that the small farmers was found to be maximum with 33.05 per cent has been generated more employment as average of 5.90 mandays / family through the crop activities, but the per cent change in employment is less (14.21 per cent) on large farmers, followed by medium farmers (26.32 per cent) and it was found 28.42 per cent on semi-medium farmers, respectively. Further similar line of studies was also carried out by Chang et al., (1997); Walling and Sharma (2015); Singh et al., (2018).

The main conclusions emerged from the present study was the most common entry point activity carried out by IWMP in Nagaland is construction of water tank / pond or reservoir followed by construction of marketing shed in and around the villages, while the most common activity implemented by IWMP scheme was the distribution of saplings followed by funding of SHG's, conducting trainings, animal husbandry, demonstration, agri-based activity and exposure trips etc. The large farmers have highest per cent of increase on their net return over small, semi-medium and medium farmers, respectively. Whereas the marginal propensity to consume was found highest for semi-medium farmers as compared to medium, small and large farmers groups, respectively.

\section{Policy implications}

The following policies implication may be drawn from the present study that the information centre should be set up at the block level, timely dissemination of the information to the beneficiaries, more focused should be on skilled based training, the financial assistance provided by the government for their livelihood activity should be enhanced and given in the appropriate time, training institute should be set up at block level for value added product / post-harvest management, watershed training programme should be conducted and further emphasis must be given for the proper utilization of fund with in time frame and adequate measures should be taken to set up market-led agencies.

\section{References}

Analogous. 2012. Agricultural Situation in India. Directorate of Economics and Statistics. Ministry of Agriculture, New Delhi.

Analogous. 2017. Statistical Hand of Nagaland Published by Directorate of Economics \& Statistics, Kohima, Nagaland.

Braden, J. B. and Vanierland, E. E. 1999. Balancing: The economic approach to sustainable water management. Water Science and Technology. 39(5): 17-23. 
Chandel, S. R. S. 1984. A Hand Book for Agricultural Statistics. Atul Prakashan Mandir, Pandu Nagar, Kanpur (U. P.).

Chang, N. B., Wen, G. E. and Chen, Y. L. 1997. A fuzzy multi-objective programming approach for optimal management of the reservoir watershed. European Journal of Operational Research. 99: 89-302.

Devi, K. R. L. 1994. Employment and income gain ratio in rural women. Yojana. 38(1): 5-7.

McDonald, L. A. and Johns, G. M. 1999. Integrating social benefit cost accounting into watershed management. Journal of Environmental Economics and Management. 38(1): 97-120.

Mehmet, Karpuzcu, and Sermin, Delipinar, 2011. Integrated Watershed Management: Socio Economic perspectives. TOJSAT. 1(3): 34-39.

Mishra, A., Pattnaik, B. R., Ray, Plabita. 2014. Impact of Watershed Development Programme on Socioeconomic Development of the People. Journal of Extension Education. 39(1): 182-189.

Ninan, K. N. and Lakshmikanthamma, S. 2001. Social cost-benefit analysis of a watershed development project in Karnataka, India. Ambio. 30(3):157161.

Onal, H., Algozin, K. A., lsik, M. and Hornbaker, R. H. 1998. Economically efficient watershed management with environmental impact and income distribution goals. Journal of Environmental Management. 53: 241253.

Paney, Yani and Sharma Amod. 2018. Prioritization Strategies for the Resources of Traditional Paddy-CumFish Culture in Lower Subansiri District of Arunachal Pradesh. IJCMAS. 7(5). May: 1112-1124.
Pannu, H. R., Lakhera, J. P, Yadav, J. P., and Jeengar, K. C. 2017. Constraints Perceived in Adoption of Indigenous Water Harvesting Practices. Indian Research Journal of Extension Education. 17(2): 121-124.

Prato, T. 1999. Risk-based multiattribute decision-making in property and watershed management. Natural Resource Modeling. 12(3): 307-334.

Prato, T. and Hajkowicz, S. 1999. Selection and sustainability of land and water resource management systems. Journal of the American Water Resources Association. 35(4): 739-752.

Raju, T., Sharma, J. P. and Singh, Premlata Lata. 2015. Impact of Watershed Development. Journal of Community Mobilization and Sustainable Development. 10(2): 15-21.

Raju, T., Sharma, J. P., Singh, Premlata Lata. and Padaria, R. N. 2012. Socio Economic Impact of Watershed Development. Journal of Community Mobilization and Sustainable Development. 7(2): 158-164.

Sharma, A. 2002. Source and Knowledge on beneficiaries about the purpose of credit - A case study of Agra Region of Uttar Pradesh. Journal of Interacademica. 6(3). July: 374-379.

Sharma, Amod. 2014. Sustainable economic analysis and extent of satisfaction level of King Chilli growers in Nagaland. Agriculture for Sustainable Development. 2(1). June: 188-191.

Singh, Jaspal. Sharma, Amod., Tyagi, D. B. and Singh, S. P. 2018. Impact of SocioEconomic Variables on the Knowledge and Adoption of the Diversified Agriculture Technologies - A Case Study of DASP adopted villages of Sasni block of Hathras District (UP). IJCMAS. 7(5). May: 3095-3102.

Singh, S. B. and Prakash, N. 2010. Socioeconomic Impact of Watershed 
Development Project in Manipur. Walling, Imti; Sharma, Amod; Yadav, IRJEE. 10(1): 78-82. Mukesh. Kumar; Rajbhar, Arun, Kumar Walling, Imti. and Sharma, Amod. 2015. Impact of SGRY on beneficiaries and non-beneficiaries in Dimapur district of Nagaland. TJRAR. 15(2). August: 9094. and Kalai, Kankabati. 2017. Impact of Agricultural Technology Management Agency on Rural Economy of Nagaland, India. Plant Archiver. 17(2). October: 1511-1516.

\section{How to cite this article:}

Kanitoli Chishi, S. and Amod Sharma. 2018. A Sustainable Impact Assessment Approach to Integrated Watershed Development Programme in Nagaland, India. Int.J.Curr.Microbiol.App.Sci. 7(11): 1661-1668. doi: https://doi.org/10.20546/ijcmas.2018.711.189 